Teaching and Learning (2009) 5(1), 31-44

\title{
Differentiating Instruction with Digital Storytelling While Making Connections to Critical Literacy
}

\author{
DR. CANDACE FIGG \\ Brock University
}

\author{
ROBIN WARD McCARTNEY \\ University of Louisiana at Lafayette
}

\author{
WALTER GONSOULIN \\ University of Louisiana at Lafayette
}

\begin{abstract}
Incorporating digital storytelling activities into learning experiences for students not only engages students in acquisition of $21^{\text {st }}$ century skills, but also provides teachers with opportunities to differentiate instruction. This paper describes a Digital Storytelling Workshop that matched diverse student learners with teacher candidates in creating digital stories, and the resulting investigation of how participation in the project impacted the ability of student learners to demonstrate critical literacy. Data sources included exit surveys, student interviews, researcher observational field notes, and student products from the workshop. Findings indicated that the digital story-making process engaged students in all levels of higher order thinking skills (Anderson \& Krathwohl, 2001) and at least one component of critical literacy, identified by Wolk (2003), as advocacy, evaluating or solving real-world problems, or making reflective connections between classroom content and culture and/or society.
\end{abstract}

\section{Introduction}

The art of storytelling has been described as the earliest form of teaching (Pedersen, 1995). In today's classroom, computer technology provides teachers with the ability to enhance their storytelling with images, sound, video, and animations, often with one mouse click. That art form, called digital storytelling, has brought positive changes to classroom teaching. As teachers become more familiar with digital tools, they are designing lessons that not only use digital storytelling techniques as an integrated natural part of their instructional practices, but digital storytelling is included in these lessons as a means of documenting and assessing student learning through student-created digital story products. These learning activities require inventive thinking, effective communication, and high productivity, as well as promote digitalage literacy, which are the $21^{\text {st }}$ century literacy skills described by North Central Regional Educational Laboratory (NCREL) (2003) as leading to increased student achievement. 
Differentiating Instruction with Digital Storytelling While Making Connections to Critical Literacy

Incorporating digital storytelling activities into learning experiences for students not only engages students in acquisition of $21^{\text {st }}$ century skills, but also provides teachers with opportunities to differentiate instruction (Smith \& Throne, 2007). Smith and Throne (2009) highlighted four elements of instruction (content, process, product, and learning environment) that can be adjusted to differentiate for individual students' needs. Digital story creation addresses these elements by requiring students to process and integrate information with other content, then express that knowledge in a personal, and often, unique product, while participating in a learning environment that is motivational, satisfying to students, and requires higher level thinking skills (Robin, 2008; Sadik, 2008; Banister, Hodges, \& Michalski, 2005; Kenny, 2007).

Anderson and Krathwohl (2001) describe this problem-solving process of using higher order thinking skills (analysis, evaluation, and creation) to synthesize a new product from foundational understandings across four types of knowledge (factual, conceptual, procedural, and metacognitive), as critical thinking skills. When these analytical thinking skills combine with a "desire to evaluate society and the world" (Anderson \& Krathwohl, 2001, p. 102) in such a way that students apply these evaluation techniques to their everyday lives through discussion, reading, writing, and creative expression, critical literacy is demonstrated (Wolk, 2003). Tompkins (2005) states that critical literacy focuses on "the empowering role of both oral and written language" so that all six language arts - writing, listening, talking, reading, viewing, and visually representing - are used to communicate, solve problems, and persuade others to a course of action (p. 22). At this point, digital storytelling becomes meaningful learning and is valuable to audiences outside the school community (Peck \& Dorricott, 1994).

The Project

Digital storytelling is a natural vehicle for stimulating critical literacy skills given that the process of creating digital stories provides learners with opportunities to use the elements of language arts to become "agents of social change" (Tompkins, 2005, p. 22). The purpose of this study was to investigate how student learners would demonstrate critical literacy through the use of technology integrated with the practice of storytelling, while engaged in a digital storytelling workshop. 
Differentiating Instruction with Digital Storytelling While Making Connections to Critical Literacy

Children for this study were recruited from a summer enrichment program sponsored by a local community non-profit organization for children of minority, low socioeconomic families with low academic achievement scores on board-mandated tests. Only children meeting these criteria and whose parents agreed to volunteer time to the program on a consistent basis were selected for the program.

Forty-five children, ages 9-12, including 20 female and 25 males, were invited to the university to participate in the workshop. Each child was teamed with a teacher candidate who was responsible for teaching their assigned student(s) how to create their own digital movie. The teacher candidates were asked to facilitate the creative process for the students rather than dictate story development by guiding the children through three activities.

Activity 1 Oral Story: First, the teacher candidate engaged the child in oral story by providing 10-12 images to initiate discussion of possible story ideas related to a specific topic. For example, many of the teacher candidates had Science teachables so they brought images of insects, food groups, or animals to stimulate story discussion. Teacher candidates with English teachables chose broad topics, such as a favorite vocalist or sport, whereas teacher candidates with Math teachables brought in problems that required problem-solving strategies, such as how many miles it took to travel from their home to another city. Some of the teacher candidate and child "pairs" used the Internet to research information and collect other images to support story ideas that would present the child's understanding of the content objective.

Activity 2 Storyboarding: Next, the teacher candidate guided the child in creating a storyboard that would lay out the story into sequenced events that could be used to create a movie. Accuracy of content was checked in the storyboards by the teacher candidates, but the children were encouraged to make decisions about how to build and organize their ideas into a cohesive and logical story (see Appendix A: Portion of Completed Storyboard for "Erosion" Video).

Activity 3 Movie Creation: The teacher candidate assisted the child in building the story into a video that incorporated images and sound using iMovie, a video editing tool. Each child completed a movie, burned it to a $\mathrm{CD}$, and took it back to the summer enrichment program to share with parents and community members. 
Differentiating Instruction with Digital Storytelling While Making Connections to Critical Literacy

\section{Data Sources}

Data sources included exit surveys, exit interviews, researchers' observational field notes, and student products. Exit surveys provided information regarding student understanding of the storytelling process and the content knowledge student learners acquired while developing digital stories. Open-ended questions during exit interviews with all student learners allowed the participants to comment on any aspects of their workshop experience. Researchers' observational field notes provided an overview of the teamwork experienced by the teacher candidate and child, in order to write stories, create storyboards, and build movies. The student work products, including storyboards and final movie projects, were collected as evidence of student application of problem-solving and higher order thinking skills.

\section{Data Analysis}

Using content analysis (Patton, 2002), three researchers, reading independently through field notes of observations of participants during the workshop, transcripts of individual interviews, and comments recorded during exit surveys, unitized the data and identified the key descriptor phrases. Key descriptor phrases were aggregated and categorized into general coding categories of thinking skills from Bloom's Taxonomy (Anderson \& Krathwohl, 2001). For example, one student learner explained that she had used the Internet to find facts about frogs so that her story would be accurate. This unit of data was given the descriptor phrase, "factual knowledge," and coded as the general category from Bloom's Taxonomy-Remember — that is characterized by actions requiring thinking skills related to factual understanding and processing. Other samples of actions leading to general categories from Bloom's Taxonomy are described in Table 1. (see Appendix B: Sample of Analysis of Actions, Key Descriptors, and Associated Category from the Revised Taxonomy of the Cognitive Domain [Anderson \& Krathwohl, 2001]).

Student work products were also analyzed for evidence of the four components of critical literacy: connections between subject content and culture or society, advocacy, evaluation of real-world problems, and suggested solutions to real-world problems as defined by (Wolk, 2003; 
Differentiating Instruction with Digital Storytelling While Making Connections to Critical Literacy

Tompkins, 2005; Goodman, 2005). Independently, two researchers reviewed student products using the rubric shown in Table 2. (see Appendix C: Sample of Coding of Student Product for Critical Literacy Components Coding of student product "Euler and the Konigsberg Bridges").

\section{The Findings}

The research question, "How would student learners demonstrate critical literacy through the use of technology integrated with the practice of storytelling?" was answered through contextual analysis of exit surveys, student interviews, and researcher observational field notes, as well as analysis of student products for components of critical literacy.

Contextual analysis indicated that the digital "story-making/storytelling" project engaged students at all levels of thinking skills as described by Anderson and Krathwohl's (2001) Revised Taxonomy of the Cognitive Domain. For example, the student product entitled, Amazon, found at http://www.youtube.com/watch?v=TDgSJIRnRSo blends creativity and interdisciplinary discussion with higher-order thinking skills. Comments from student learners in their interviews and exit surveys also pointed out the level of challenge the experience provided. The following comments are representative:

Making this movie really made me think!

I used computers at home and school, but for lower skills, like surfing the Internet and getting facts.

Other comments illustrated content knowledge gained.

I had only used computers before to play games, but the teacher made me think about things-I learned a lot of things about ladybugs.

I didn't know how to write a poem, but the teacher helped me to rhyme words. 
Differentiating Instruction with Digital Storytelling While Making Connections to Critical Literacy

The analysis of student products shown in Table 3 further revealed that all products demonstrated higher order thinking skills combined with at least one component of critical literacy, identified as advocacy, evaluating or solving real-world problems, or making reflective connections between classroom content and culture and/or society (Wolk, 2003; Tompkins, 2005; Goodman, 2005). (see Appendix D: Analysis of Components of Critical Literacy [CLC]).

Making reflective connections between classroom content and culture and/or society. Of the 41 student products created during the workshop sessions, all contained evidence of the student author using higher order thinking skills to make connections-either for purposes of connecting the new knowledge to culture and/or society, or for advocacy purposes, or for evaluating and even proposing solutions to real-world problems. All student products made personal connections between the content and the student learner's own culture or society. Some of the student products in this category clearly expressed the link between the student learners' research and new knowledge in relation to their own culture and society, and included "Cooking with Chef Alexis (Edible Bugs)," "Hurricanes," "My Dog, Buddy,” and “Alicia Keys.” (See $A$ Beautiful Ladybug available at http://www.youtube.com/watch?v= wcoIKFOOBo and A Frog's Life available at http://www.youtube.com/watch?v=AOoQBdDXHhY.)

Evaluating and solving real-world problems. By developing storytelling in combination with digital video skills, approximately $34 \%$ of student learners were able to authentically interact with the teacher candidate to evaluate real-world problems, with $37 \%$ demonstrating the ability to pose solutions to real-world problems. This collaborative process facilitated the child's opportunity to increase vocabulary, refine speaking skills, and improve listening skills. Erosion, Amazon Rain Forest, Distance and Travel, and Substance Abuse, were just a few of the products that were enhanced by the collaborative experience between teacher candidate and student. Another example, Euler and the Konigsberg Bridges Problem (available at http://www.youtube.com/watch? $\mathrm{v}=\mathrm{fCpz} 3011 \mathrm{~b} 5 \mathrm{E})$, was the result of a visual provided by the teacher candidate. The student, skillfully guided by the teacher candidate, worked through the problem-solving process required to move the computer cursor around a figure 8 without crossing the "bridges" twice. Then, the student created a story that detailed the problem and provided the solution. 
Differentiating Instruction with Digital Storytelling While Making Connections to Critical Literacy

Advocacy. Only $24 \%$ of student products were identified as examples of advocacy. A twelve-year-old female student used this learning experience to express her concerns and views about animals on display at the zoo. In her video, Locked in a Zoo, the female student learner passionately appealed to her audience to understand the need for animals to be allowed to live in their natural habitat. She advocated for the release of the animals and depicted zoos as a cruel environment (see Locked in a Zoo at http://www.youtube.com/watch?v=NxhMh85Ge5g). This sense of advocacy was also visible in the product of a ten-year-old male student learner. He stressed the importance of saving the Louisiana coastline and offered suggestions as to how it could be done (see Erosion at http://www.youtube.com/watch?v=SFo4yQ-dzaA).

\section{Discussion and Implications}

Adapting instruction so that learning activities support multiple means of student learning is at the center of the teaching strategy of differentiating instruction. Digital storytelling is differentiated learning as it promotes personalized learning that is enhanced with multimedia components which students find motivational (Jonassen, Howland, Marra, \& Crismond, 2008; Center for Applied Research in Educational Technology [CARET], 2005).

However, projects such as these often take time - time for students to create, revise, process, and explore. All participants in this study felt that more time was necessary to allow students to practice with the digital video creation tools. Addressing the time factor would allow student learners to create broader associations between the content and cultural or social understandings needed for deeper and more far-reaching insights to occur, leading to student products demonstrating more components of critical literacy. To fully support the development of critical literacy, student learners would need opportunities to select their own topics, as well as participate in the problem-solving activities required to complete a digital story.

Yet, both student learners and teacher candidates were satisfied with the experience. Student learners commented that it was "awesome," "my favorite field trip," and "interesting and fun." Other comments demonstrated that student learners valued the experience because it was on the university campus, incorporated technology, and allowed them to work with the teacher candidates. Interview comments included: 
Differentiating Instruction with Digital Storytelling While Making Connections to Critical Literacy

I learned a lot about hurricanes - the eye of the storm is the calmest part-and the teacher was good and really fun and explained everything in a way I could understand it.

I was able to use my own picture in the movie because of the great on-site tools.

I had to do all kinds of stuff like get pictures and talk into a [microphone] and listen to our voice.

I was excited because it was my first time on campus.

I liked being at college. It was interesting and fun.

I thought it would be hard and was nervous, but the teacher helped me and made me feel comfortable.

Even parents attending the workshop as chaperones expressed excitement at the depth of meaningful learning the digital storytelling experience provided for students.

It was interesting because it was hands-on experience and incorporated a variety of subject matter with technology.

They are all into it and they are learning.

When technology is integrated with a learning environment, it often facilitates what Britton (1990) describes as "natural learning"_or, dialogues and interactions with other students and sometimes the teacher. Smith \& Thorne (2007) add that integrating technology into teaching strategies "can help teachers shape and deliver instruction to meet the needs of all students, assist in the improvement of student thinking, provide for research and presentation products, and improve communication" (p. 13). The implications for teachers who wish to incorporate digital storytelling into learning experiences for their own students, is that the class time used in projects 
Differentiating Instruction with Digital Storytelling While Making Connections to Critical Literacy

such as these may be more than required for other activities. However, that time is well worth taking, as it results in students who are "encouraged to think more deeply about the meaning of the topic or story and personalize their experience and also clarify what they knew about the topic before and during the process of developing and communicating their stories" (Sadik, 2008, p. 502).

\section{Conclusion}

Why have students create digital stories? By developing storytelling in combination with digital video skills, students were able to authentically interact with a knowledgeable other, (the teacher candidate), in an engaging and challenging learning situation. All student learners involved in this project were performing higher order thinking processes and following diverse cognitive and affective strategies. Using the power of story to differentiate learning for students not only motivated students, regardless of their culture, ethnicity, gender, age, language, ability level, race, or content area, to perform at high levels of understanding, but engaged them in one cornerstone of critical literacy — using language as a "way of organizing knowledge within a cultural and political context” (Tompkins, 2005, p. 23). Livo and Rietz (1986) explain the power of story in this way:

Story is a universal mirror that shows us the truth about ourselves-who and why we are. When we look into this mirror, we see daily routine and mundane circumstances transformed into something profound; story takes the ordinary and binds it into all of human existence, revealing the significance of the trivial (p. 4).

\section{References}

Anderson, L. W., \& Krathwohl, D. R. (Eds.). (2001). A taxonomy for learning, teaching, and assessing: A revision of Bloom's taxonomy of educational objectives. New York: Longman.

Banister, S., Hodges, D., \& Michalski, P. (2005). Digital storytelling in the middle childhood special education classroom: A teacher's story of adaptations. TEACHING Exceptional Children Plus, 1(4), 3. Retrieved April 5, 2009, from http://escholarship.bc.edu/education/tecplus/vol1/iss4/art3/ 
Differentiating Instruction with Digital Storytelling While Making Connections to Critical Literacy

Britton, J. (1990). Research currents: Second thoughts on learning. In M. Brubacher, R. Payne, \& K. Richett (Eds.), Perspectives on small group learning: Theory and practice. (pp. 311). Oakville, ON: Rubicon.

Center for Applied Research in Educational Technology (CARET). (2005). Student learning. Retrieved April 1, 2009, from http://caret.iste.org/index.cfm?fuseaction=answers\&QuestionID=1

Goodman, S. (2005). The practice and principles of teaching critical literacy at the Educational Video Center. Yearbook of the National Society for the Study of Education, 104(1), 206228.

Jonassen, D., Howland, J., Marra, R., \& Crismond, D. (2008). Meaningful learning with technology. Upper Saddle River, NJ: Pearson.

Kenny, R. F. (2007). Digital narrative as a change agent to teach reading to medi-centric students. International Journal of Social Sciences, 2(3), 187-195.

Livo, N. S., \& Reitz, S. A. (1986). Storytelling: Process and practice. Littleton, CO: Libraries Unlimited.

North Central Regional Educational Laboratory (NCREL) and the Metiri Group. (2003). enGauge ${ }^{\circledR} 21^{\text {st }}$ century skills: Literacy in the digital age. Naperville, IL: Learning Point Associates.

Patton, M. Q. (2002). Qualitative research and evaluation methods. Thousand Oaks, CA: SAGE Publications.

Peck, K. L., \& Dorricott, D. (1994). Why use technology? Educational Leadership, 51(7), 11-15. Retrieved April 1, 2009, from http://www.ascd.org/publications/educational_leadership/apr94/vol51/num07/Why Use Technologyc.aspx

Pedersen, E. M. (1995). Storytelling and the art of teaching. English Teaching Forum, 33(1), 2-5.

Robin, B. (2008). Digital storytelling: A powerful technology tool for the $21^{\text {st }}$ century classroom. Theory into Practice, 47(3), 220-228. Retrieved February 9, 2009, from http://www.informaworld.com/smpp/title $\sim$ content $=\mathrm{t} 775653706$

Sadik, A. (2008). Digital storytelling: A meaningful technology-integrated approach for engaged student learning. Education Tech Research Development, 56, 487-506.

Smith, G. \& Thorne, S. (January 28, 2009). Webinar: Differentiated instruction + tech $=$ powerful learning. International Society for Technology in Education (ISTE).

Smith, G. \& Thorne, S. (2007). Differentiating instruction with technology in K-5 classrooms. Eugene, OR: International Society for Technology in Education (ISTE).

Tompkins, G. (2005). Language arts: Patterns of practice. Upper Saddle River, NJ: Prentice Hall.

Wolk, S. (2003). Teaching for critical literacy in Social Studies. Social Studies, 94(3), 101-106. 
Differentiating Instruction with Digital Storytelling While Making Connections to Critical Literacy

\section{Appendix A}

Portion of Completed Storyboard for "Erosion" Video

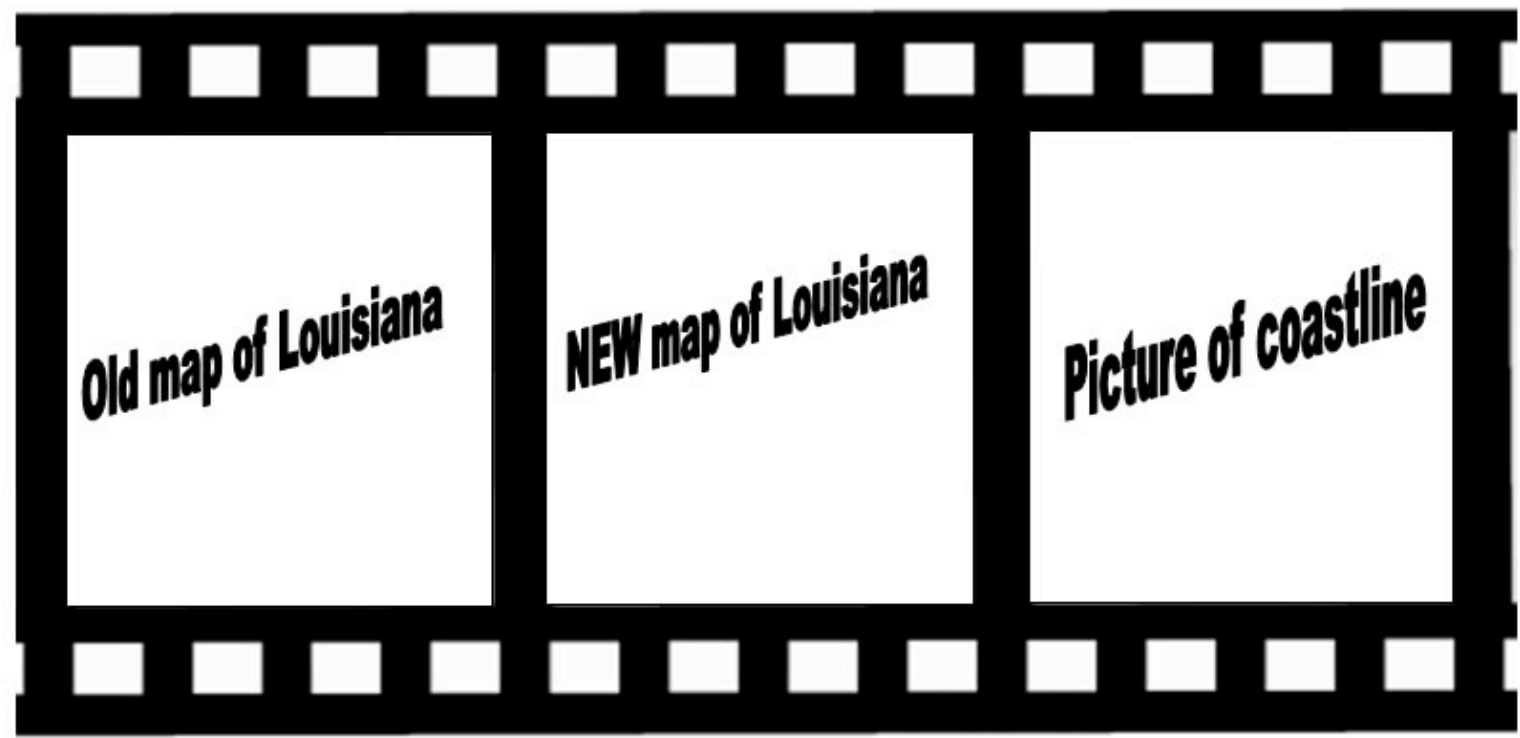

\begin{tabular}{|l|l|l|}
\hline SCENE \#1 & SCENE \#2 & SCENE \#3 \\
\hline $\begin{array}{l}\text { Script: This is a map of Louisiana a hundred } \\
\text { years ago. }\end{array}$ & $\begin{array}{l}\text { Script: This is a map of Louisiana today. } \\
\text { Notice the difference? }\end{array}$ & $\begin{array}{l}\text { Script: Erosion has taken away much of } \\
\text { our land over many years. }\end{array}$ \\
\hline Sound Effects and/or Background Music: & Sound Effects and/or Background Music: & Sound Effects and/or Background Music: \\
\hline & & \\
\hline Notes: & Notes: & Notes: \\
\hline
\end{tabular}


Differentiating Instruction with Digital Storytelling While Making Connections to Critical Literacy

\section{Appendix B}

Table 1

Sample of Analysis of Actions, Key Descriptors, and Associated Category from the Revised Taxonomy of the Cognitive Domain (Anderson and Krathwohl, 2001)

\begin{tabular}{|c|c|c|}
\hline Category & Key Descriptor & Action \\
\hline \multirow[t]{9}{*}{ Remember } & \multirow[t]{4}{*}{ Factual Knowledge } & Students used the Internet to research factual content of their story. \\
\hline & & Students described and labeled the pictures used in the story. \\
\hline & & $\begin{array}{l}\text { Students wrote down basic text and drew pictures in their } \\
\text { storyboards. }\end{array}$ \\
\hline & & $\begin{array}{l}\text { Students orally communicated their story idea by reciting the } \\
\text { content of their story to their teacher candidates. }\end{array}$ \\
\hline & \multirow[t]{2}{*}{ Procedural Knowledge } & Students identified and named objects and events in their stories. \\
\hline & & $\begin{array}{l}\text { Students recalled basic technical functions on the computer in order } \\
\text { to make their iMovie. }\end{array}$ \\
\hline & \multirow[t]{2}{*}{ Conceptual Knowledge } & $\begin{array}{l}\text { Students chose new pictures to use in their story to represent their } \\
\text { ideas from other resources. }\end{array}$ \\
\hline & & $\begin{array}{l}\text { Students discussed ideas with teacher candidates to ensure } \\
\text { accuracy. Teacher candidates helped them with their } \\
\text { misconceptions. }\end{array}$ \\
\hline & Meta-Cognitive Knowledge & Students used the pictures to help them remember the story. \\
\hline
\end{tabular}


Differentiating Instruction with Digital Storytelling While Making Connections to Critical Literacy

\section{Appendix C}

Table 2

Sample of Coding of Student Product for Critical Literacy Components Coding of student product "Euler and the Konigsberg Bridges"

\begin{tabular}{|c|c|c|c|c|}
\hline $\begin{array}{l}\text { Critical } \\
\text { Literacy } \\
\text { Category }\end{array}$ & $\begin{array}{l}\text { Exemplary } \\
\text { Example- } \\
\text { treatment is } \\
\text { thorough and } \\
\text { connection is } \\
\text { very evident }\end{array}$ & $\begin{array}{l}\text { Satisfactory } \\
\text { evidence of this } \\
\text { component but } \\
\text { treatment could } \\
\text { have been more } \\
\text { thorough }\end{array}$ & $\begin{array}{l}\text { Little, but } \\
\text { some evidence } \\
\text { of this } \\
\text { component }\end{array}$ & $\begin{array}{c}\text { No Evidence } \\
\text { of this } \\
\text { component }\end{array}$ \\
\hline$A=A d v o c a c y$ & & & & $\begin{array}{l}\text { Although } \\
\text { problem is } \\
\text { depicted, there is } \\
\text { no evidence of } \\
\text { advocacy }\end{array}$ \\
\hline $\begin{array}{l}E=\text { Evaluation } \\
\text { of Real-World } \\
\text { Problem }\end{array}$ & $\begin{array}{l}\text { Clear explanation } \\
\text { of real bridges } \\
\text { and the problem } \\
\text { to be solved in } \\
\text { student product }\end{array}$ & & & \\
\hline $\begin{array}{l}\mathrm{S}=\text { Solution to } \\
\text { Real-World } \\
\text { Problem }\end{array}$ & $\begin{array}{l}\text { Student product } \\
\text { clearly depicts } \\
\text { solution so } \\
\text { audience can find } \\
\text { the solution as } \\
\text { well! }\end{array}$ & & & \\
\hline $\begin{array}{l}\mathrm{C}=\text { Connection } \\
\text { between } \\
\text { content and } \\
\text { culture or } \\
\text { society }\end{array}$ & $\begin{array}{l}\text { Student product } \\
\text { clearly outlines } \\
\text { the content and } \\
\text { related the } \\
\text { problem to the } \\
\text { German culture }\end{array}$ & & & \\
\hline
\end{tabular}


Differentiating Instruction with Digital Storytelling While Making Connections to Critical Literacy

\section{Appendix D}

Table 3

Analysis of Components of Critical Literacy (CLC)

\begin{tabular}{|c|c|c|c|c|c|}
\hline & \multicolumn{2}{|c|}{ Product Information } & \multicolumn{2}{|c|}{$\begin{array}{c}\text { Student } \\
\text { Information } \\
\end{array}$} & \multirow{2}{*}{$\begin{array}{c}\text { CLC** } \\
* \text { See Codes Below }\end{array}$} \\
\hline No & Title of iMovie & Subject Area & Gender & Age & \\
\hline 1 & The Past Time & Social Studies & Female & 9 & $\mathrm{C}$ \\
\hline 2 & Erosion & Science & Male & 11 & $\mathrm{C}, \mathrm{A}, \mathrm{E}$ \\
\hline 3 & My Dog Buddy & English/LA & Female & 12 & $\mathrm{C}$ \\
\hline 4 & My Animals & Science & Male & 11 & $\mathrm{C}$ \\
\hline 5 & Animals & Science & Male & 10 & $\mathrm{C}$ \\
\hline 6 & Animals Life & Science & Female & 12 & $\mathrm{C}$ \\
\hline 7 & A Tour at the Zoo & Science & Male & 10 & $\mathrm{C}$ \\
\hline 8 & $\begin{array}{l}\text { Euler and the Konigsberg Bridges } \\
\text { Problem }\end{array}$ & Math/Social Studies & Male & 9 & $\mathrm{C}, \mathrm{E}, \mathrm{S}$ \\
\hline 9 & Alicia Keys & English & Female & 12 & $\mathrm{C}$ \\
\hline 10 & The Life \& Times of Michael Jordan & English & Male & 12 & $\mathrm{C}$ \\
\hline 11 & Alligators & Science & Male & 12 & $\mathrm{C}, \mathrm{A}, \mathrm{E}$ \\
\hline 12 & Louisiana Outdoors & Social Studies & Male & 10 & $\mathrm{C}$ \\
\hline 13 & What in the World? & Science & Female & 13 & $\mathrm{C}$ \\
\hline 14 & Hurricanes & Science & $\begin{array}{l}\text { Female } \\
\text { Male }\end{array}$ & $\begin{array}{l}12 \\
10\end{array}$ & $\mathrm{C}, \mathrm{E}$ \\
\hline 15 & The Beautiful Lady Bug & Science & Female & 11 & $\mathrm{C}$ \\
\hline 16 & Locked in a Zoo & Science & Female & 12 & $\mathrm{C}, \mathrm{A}, \mathrm{E}, \mathrm{S}$ \\
\hline 17 & Tornadoes & Science & Male & 11 & $\mathrm{C}, \mathrm{E}$ \\
\hline 18 & Only Ten Dollars & Math & Female & 11 & $\mathrm{C}, \mathrm{E}, \mathrm{S}$ \\
\hline 19 & Distance and Travel & Math & Male & 12 & $\mathrm{C}, \mathrm{E}, \mathrm{S}$ \\
\hline 20 & My Bananas & Math & Female & 10 & $\mathrm{C}$ \\
\hline 21 & Life in Vietnam & Social Studies & Female & 13 & $\mathrm{C}, \mathrm{E}$ \\
\hline 22 & The Hungry Farmer & Science & Male & 10 & $\mathrm{C}$ \\
\hline 23 & Hurricanes & Science & Male & 9 & $\mathrm{C}, \mathrm{E}$ \\
\hline 24 & Animal Homes & Science & Female & 9 & $\mathrm{C}$ \\
\hline 25 & Mickey \& Florida & Social Studies & Female & 10 & $\mathrm{C}, \mathrm{A}$ \\
\hline 26 & Crawfish & Science & Female & 9 & $\mathrm{C}, \mathrm{A}, \mathrm{E}, \mathrm{S}$ \\
\hline 27 & Amazon Rain Forest & Science & Male & 10 & $\mathrm{C}, \mathrm{A}, \mathrm{E}$ \\
\hline 28 & Lady Bugs & Science & Female & 9 & $\mathrm{C}$ \\
\hline 29 & Presidents & Social Studies & Male & 9 & $\mathrm{C}$ \\
\hline 30 & Butterflies & Science & Male & 11 & $\mathrm{C}$ \\
\hline 31 & Dinosaurs & Science & Male & 10 & $\mathrm{C}$ \\
\hline 32 & Louisiana Tour & Social Studies & $\begin{array}{c}\text { Male } \\
\text { Female }\end{array}$ & $\begin{array}{l}11 \\
10\end{array}$ & $\mathrm{C}, \mathrm{A}$ \\
\hline 33 & A Frog's Life & Science & Female & 9 & $\mathrm{C}$ \\
\hline 34 & Cooking with Chef Alexis (Edible Bugs) & Science & Female & 10 & $\mathrm{C}, \mathrm{A}, \mathrm{S}$ \\
\hline 35 & The 4th of July & Social Studies & Male & 12 & $\mathrm{C}$ \\
\hline 36 & Welcome to Louisiana & Social Studies & $\begin{array}{l}\text { Female } \\
\text { Male }\end{array}$ & $\begin{array}{l}10 \\
10\end{array}$ & $\mathrm{C}, \mathrm{A}$ \\
\hline 37 & The Digestive System & Science & Female & 10 & $\mathrm{C}$ \\
\hline 38 & $\begin{array}{l}\text { Fast Food Restaurants (Buying Meals on } \\
\text { a budget) }\end{array}$ & Math & Male & 9 & $\mathrm{C}, \mathrm{E}, \mathrm{A}$ \\
\hline 39 & Parts of the Plant & Science & Male & 9 & $\mathrm{C}$ \\
\hline 40 & Substance Abuse & Health & $\begin{array}{l}\text { Male } \\
\text { Male }\end{array}$ & $\begin{array}{c}9 \\
10\end{array}$ & $\mathrm{C}, \mathrm{E}, \mathrm{S}$ \\
\hline 41 & Plants of the Jungle & Science & Male & 9 & $\mathrm{C}$ \\
\hline & $* *$ Codes & Comnonents & tical Lit & $\operatorname{acy}$ & \\
\hline$A=A$ & dvocacy & or Components & $24 \%$ of & oducts & \\
\hline $\mathrm{E}=\mathrm{E}$ & aluation of Real-World Problen & & $34 \%$ of & oducts & \\
\hline $\mathrm{S}=\mathrm{S}$ & lution to Real-World Problem & & $37 \%$ of & oducts & \\
\hline $\mathrm{C}=\mathrm{C}$ & nnection between content and & lture or Society & $100 \%$ o & roduct & \\
\hline $\mathrm{X}=\mathrm{N}$ & o critical literacy evidence & & $0 \%$ of $p$ & ducts & \\
\hline
\end{tabular}

